\title{
THE ROLE OF CAREER DEVELOPMENT IN IMPROVING EMPLOYEE PERFORMANCE: EMPIRICAL STUDY ON PRIVATE HIGHER EDUCATION IN CENTRAL JAVA, INDONESIA
}

\author{
Suparjo \\ Program Magister Manajemen Fakultas Ekonomika dan Bisnis UNTAG Semarang \\ Email: suparjo_ws@yahoo.com \\ Endang Sri Sunarsih \\ Medicine Faculty, Diponegoro University \\ Email: endss2007@yahoo.co.id \\ Received: May 2019; Accepted: July 2019; Available online: July 2019
}

\begin{abstract}
This paper main objective was to investigate whether career development has impact on employees performance. This paper is quantitative in nature. Data for the paper have been collected through primary source that are from questionnaires surveys. The data have been checked through statistical software to find the impact of career counseling on worker efficiency, and career mentoring and skill assessment on employees performance. The population of this study was 1,116 lecturers and administrative staff of 10 Private Higher Education in Central Java, Indonesia., and the taken sample was 250 respondents. Descriptive statistic tools SPSS were applied on the questionnaire to see the reliability and consistency. The result showed that career counseling had a positive and significant effect on worker efficiency, and career mentoring and skill assessment had a positive and significant effect on employees performance. The study recommends that organizations should encourage career counseling activities as a leeway of providing a sustainable framework upon which employees acquire the needed operational skills that will enhance their job performance in a typical organization.
\end{abstract}

Keywords: career counseling, career mentoring, skill assessment, job performance.

\begin{abstract}
Abstrak
Tujuan utama makalah ini adalah untuk menyelidiki apakah pengembangan karir berdampak pada kinerja karyawan. Makalah ini bersifat kuantitatif. Data untuk makalah telah dikumpulkan melalui sumber utama yang berasal dari survei kuesioner. Data telah diperiksa melalui perangkat lunak statistik untuk menemukan dampak konseling karir pada efisiensi pekerja, dan mentoring karir dan penilaian keterampilan pada kinerja karyawan. Populasi penelitian ini adalah 1.116 dosen dan staf administrasi 10 Perguruan Tinggi Swasta di Jawa Tengah, Indonesia., Dan sampel yang diambil adalah 250 responden. Alat statistik deskriptif SPSS diterapkan pada kuesioner untuk melihat keandalan dan konsistensi. Hasil penelitian menunjukkan bahwa konseling karir berpengaruh positif dan signifikan terhadap efisiensi pekerja, dan mentoring karir dan penilaian keterampilan berpengaruh positif dan signifikan terhadap kinerja karyawan. Studi ini merekomendasikan bahwa organisasi harus mendorong kegiatan konseling karir sebagai kelonggaran menyediakan kerangka kerja yang berkelanjutan di mana karyawan memperoleh keterampilan operasional yang diperlukan yang akan meningkatkan kinerja pekerjaan mereka dalam organisasi yang khas.
\end{abstract}

Kata kunci: konseling karir, mentoring karir, penilaian keterampilan, prestasi kerja.

How to Cite: Suparjo \& Sunarsih, E. S. (2019). The Role of Career Development in Improving Employee Performance: Empirical Study on Private Higher Education in Central Java, Indonesia. Media Ekonomi dan Manajemen, 34(2), 193-205. 


\section{INTRODUCTION}

Today's employees are more career conscious then ever. They are demanding more in terms of personal growth and development. Organizations that fail to allow employees to meet their individual needs will be losing valued employees. Many organizations are faced with the problem of retaining employees. It is expensive to replace employees who leave for greener pastures or are lured away by other organizations. New employees have to be recruited, selected, oriented and trained. In fact, it is estimated that it costs an organization approximately $1 \frac{1 / 2}{2}$ times the salary of the vacated position to replace an employee (Merchant, Jr. 2014).

Agba, Nkpoyen and Ushie (2010) asserted that the demands of meeting the challenges of competitive nature of business environment and considerable upsurge in technological advancement, have stirred most organizations to lay emphases on career development as a necessary condition in meeting the demands of the environment. Career Development Programs have evolved because of changes in the workforce (work-life balance, diversity, and focus on quality), advances in management theory (employee motivation), changes in managerial styles and the increasing complexity of technology.

Agba et. al. (2010) asserted that where an employer can provide the worker with ample opportunities for growth and advancement, a proper attitude of loyalty and satisfaction can be enhanced. Manufacturing firms create enabling environment for career development through Human Resource Department that plans several career development programs that will dovetail employees and the organization. Hameed and Waheed (2011) argue that when organizations contribute towards employee development activities, employees work harder, utilize their skills and efforts fully to achieve the overall goal of the organization. "Career development is concerted effort directed towards assessing workers potentials, identifying likely career paths for employees, designing and implementing various forms of training and experience to prepare them for more advanced jobs (Stone, 2005).

Aldefer and Aryam (2004) argues that career development is the process by which individuals collect information about values, interests, and skill strengths and weaknesses (career exploration), identify a career goal, and engage in career strategies that increase the probability that career goals will be achieved. The career management process according to John (2000) involves career exploration, development of career goals, and use of career strategies to obtain career goals.

Career development according to Martin (2000) has increasingly become an indispensable index for skill acquisition, and operational capabilities considering the dynamic nature of business environment to the point that development of such capacities especially through training has heretofore emerged as a necessary requirement in preparing a long-term strategic plan of the organization. Klein (2009) sees career development as a sustained strategy for enhancing employee job performance in order to achieve a competitive advantage in the changing business environment. Thus, organizations strive to optimize their workforce through comprehensive career development programs in order to take abreast of its environment with respect to improved technologies, innovations and market economies. This however will enable the organizations to achieve and sustain greater operational effectiveness and efficiency that will afford them greater leverage for success (Tadic, 2007). As a result, Private University are increasingly demanding superior skills, increased productivity and work-related knowledge from their workers. These demands however emphasize the need for career development in Private Higher Education in Central Java, Indonesia. . 


\section{Statement of the Problem}

Most Private Higher Education seem to be grappling with employees' counterproductive attitudes to work, which may be attributed to the management inability to design an institutional framework that would allow for career development programs necessary for skill acquisition given the dynamism of business environment. Employee work performance is low in Private Higher Education in Central Java, Indonesia and this may be attributed to dearth of career development schemes like career counseling, career mentoring, and on-thejob training. These methods however create long-lasting experience, operational capabilities that culminate to improved organizational performance. The firm presently is faced with lack of specialized career counselors to advise employees on the rightful career development methods within the context of organizational realities. This situation tends to undermine worker efficiency of service delivery, and the realization of organizational goal (John, 2000).

Employees of the Private Higher Education in Central Java, Indonesia lack proper guidance for achieving career goals and expertise support to understand the system expectations which will enable them to be articulated and more prepared to handle roles as well as able to perform their work effectively. The aforementioned is orchestrated as a result of inadequate application of career mentoring. In addition, the efforts of employees are being affected by monotony of work and lack of innovation that causes boredom, work stress and affects interpersonal collaboration and work effectiveness. It would be difficult to determine the underlying net effect(s) of the interactions between career counseling on worker efficiency, career mentoring on quality of employee work performance and skill assessment training on efforts of employee without research-based evidence, hence this study.

\section{LITERATURE REVIEW}

\section{Components of a Career Development Program}

The desired outcome of a Career Development Program is to match the needs of the employee with those of the organization. Employees must have the opportunity to identify career needs and the organization should assist them in achieving these needs within organizational realities. Employees must have the opportunity to identify career needs while the organization should assist them in achieving these needs within organizational realities. A Career Development Program according to Hirsh (2007) does not require elaborate procedures. The essential components are career counseling, career mentoring and skill assessment.

\section{Career Counseling}

The three major paradigms of vocational psychology each provide a theoretical rational for distinct types of career counseling interventions (Savickas \& Savickas, 2017). The personenvironment model supports the practices of vocational guidance and academic advising that match individuals to college majors and jobs in which they resemble the incumbents. The career development model supports the practices of career education and coaching that teach individuals the skills need to make choices and develop their careers. The career construction model supports the practice of life designing dialogues that construct the career narratives that individuals author to impose meaning on their work and manage their careers.

One of the most logical and important aspects of the career development process involves career counseling. It is a key component or the foundation of the employee development process and can produce big dividends for both the employees and organization. An effective Career Counseling Program not only 
assists an organization in identifying employees with high performance potential but also assists employees in mapping out realistic career opportunities.

An effective Career Counseling Program does not only assist an organization in identifying employees with high performance potential but also assists them in mapping out realistic career opportunities (Tabitha, 2017). Career counseling according to John (2000) is concerned with instituting various skill acquisition programs that evolve selfunderstanding; broadening one's horizons, work selection, challenge, satisfaction, and other interpersonal matters, work site behavior, communication, and other interpersonal phenomena, and lifestyle issues, such as balancing work, family, requirement.

According to Osibanjo and Ojo (2014) the aim of career counseling to employees are as follows; understanding self, making personal decision, setting achievable goals which enhances growth and planning in the present to bring about desired future, coping with difficult solutions, controlling self-defeating emotions, acquiring effective transaction skills and acquiring positive self-regard and sense of optimism about one's own ability to satisfying one's basic needs. Therefore, the thrust of career counseling is to assist employees in exploiting their strengths and potential and avoiding mismatches between individual aspirations, capabilities and organizational opportunities. It reduces the waste of preparing an employee for a position for which they are not suited, but might otherwise accept, in order to conform to the wishes of the organization (Martin, 2000).

\section{Career Mentoring}

Supervisors play a crucial role in employee's career development by offering mentoring (Rafferty \& Griffin, 2006). Typically, two broad mentoring functions are distinguished psychosocial mentoring and career mentoring. Psychosocial mentoring refers to facilitating the development of employees' confidence and work effectiveness by providing a positive role model, counseling, and coaching (Sosik \& Godshalk, 2000), whereas career mentoring refers to instrumental assistance for career advancement. Perceptions of psychosocial mentoring are much more bound to the person of the supervisor, whereas career mentoring is apt to generating perceptions of the organization. A recent meta-analysis showed that psychosocial mentoring has a stronger influence on the relationship quality with the supervisor than career mentoring, whereas career mentoring has a stronger impact on employees' affiliation with the organization.

Supervisors who provide career mentoring give their employees challenging assignments and learning opportunities, assist them in achieving their goals, and bring them in contact with influential people in the organization (Ragins \& McFarlin, 1990). De Pater et al. (2009) showed that challenging assignments and learning opportunities foster an employee's promotability as evaluated by the supervisor. Promotability entails supervisors' "perception of an individual's capacities and willingness to effectively perform at higher levels" (De Pater et al., 2009). From an organizational perspective, the identification of promotable employees is crucial for building and developing a pool of employees who are able to fulfill a broader set of roles, which enables an organization to effectively adapt and respond to changes in the business environment (Nauta et al., 2009). For individual employees, favorable promotability evaluations create better opportunities for actual career advancement (Van Scotter, Motowidlo, \& Cross, 2000).

Whereas career mentoring seems to have a generally positive effect on career success, its relationship with intention to stay is more ambiguous because increasing 
employees' career potential might make them more suited for career opportunities outside the organization (Ito \& Brotheridge, 2005).

Mentoring is a professional relationship in which an experienced employee (mentor) assists another less experienced employee (mentee) in developing specific skills and knowledge that will enhance the less experienced person's professional and personal growth. Scandura and William (2004) define a mentor as a corporate manager who supervises, coaches, and guides selected Lower - level employees by introducing them to the right people and generally being their organizational sponsor. In reality, an informal type of mentoring goes on in most organizations on regular basis as older employees assist younger workers. Networking and having mentors is essential for succession planning because it builds and develops managers by widening their knowledge and better understanding of the overall operations and to prepare for task ahead. Agulanna and Awujo (2005) define mentoring as the process of using specially selected and trained people to provide guidance and advice which will help to develop the careers to the people allocated to them to be more efficient in improving the quality of work. Mentoring is used to complement learning on the job which of course is the best way of obtaining particular knowledge and skills.

\section{Skill Assessment}

Skills are the most important assets your employees possess. Well-honed skill sets give them the opportunity to master tasks and improve their work performance. It's vital to test both technical and soft skills when you are conducting skills assessments. This is due to the fact that both types are required in the workplace. For example, a corporate learner may know a great deal about the equipment they repair, but they might not be able to communicate effectively with clients in order to troubleshoot common issues. A technical skill is typically a skill that is closely related to a specific field or profession. A soft skill, on the other hand, is a skill that helps them relate to others, communicate, and collaborate. Simulations are one of the most effective tools for testing both types of skills, as it allows them to interact with a virtual environment, as well as characters who can test their understanding of body language, emotions, and behaviors.

Skills assessments shouldn't just be used for pre-employment purposes. By regularly assessing the skills and competencies of current staff, hiring managers will be able to have a better understanding of the skills that are needed from incoming employees.

John (2000) opines that training and development is a technique used to transfer to the employees relevant skills, knowledge and competence to improve employee performance on the current jobs and future assignment. Employee training is a necessary condition that predisposed employee to acquire certain skills, knowledge especially given the dynamic nature of business environment. Knowledge acquisition makes it absolutely imperative for employees to keep abreast of its environment with respect to unprecedented upsurge in information and communication technology. The survival of any organization in a competitive society depends on its ability to train its human resource to be innovative, creative, inventive who will invariably enhance performance and increase organization's competitive advantage. According to Nwachukwu (2000) asserts that training is a short-term educational process utilizing a systematic and organized procedure by which non-managerial personnel learn technical knowledge and skills for a definite purpose. When organization engages an employee to perform certain job and for the task to perform adequately well, there is the need to train the employee to acquire the necessary knowledge, skills and competencies to be 
able to executive the job effectively and efficiently.

Based on literature review and Figure 1, this study proposes tree hypothesis as follow:

$\mathrm{H}_{1}$ : There is a significant relationship between career counseling and worker efficiency.

$\mathrm{H}_{2}$ : There is a significant relationship between career mentoring and quality of employee job performance.

$\mathrm{H}_{3}$ : There is a significant relationship between skill assessment training and the efforts of employee job performance.

\section{RESEARCH METHODS}

The study was a survey-type of research that employed a correlational design in an attempt to determine the direction and the magnitude of the relationship between the studied variables. Structured questionnaire drawn on 5 point scale rating was administered to a sample of 250 respondents drawn from the population of the study. The test re-test approach was employed such that Cronbach Alpha coefficient was used to determine the internal reliability of the research instrument. Therefore, the reliability result yielded the Cronbach's alpha of $0.83,0.80$, and 0.78 for career counseling, career mentoring and skill assessment, respectively, and 0.89 for career development. These levels of Cronbach's alpha were considered good indicators of the reliability of the instrument. For easy estimation, simple regression was employed in each hypothesis.

\section{RESULT AND DISCUSSION}

This paper main objective was to investigate whether career development has impact on employee's performance. Table 1 shows the result of career counseling on worker efficiency in a Private Higher Education in Central Java, Indonesia.The coefficient of the constant term is - 303 and its associated t-value is statistically significant at 5\% level. This implies that at zero level of worker efficiency in the Private Higher Education in Central Java holding career counseling constant, the level of worker efficiency will decrease by $3 \%$. The regression coefficient of career counseling carries negative sign and its associated t-value is significant at $5 \%$ level of significance. The implication of the aforementioned is that worker efficiency in the Private Higher Education in Central Java, Indonesia. has a significant effect on the career development in their operations; a unit increase in the level of career development will lead to an increase in worker efficiency. Since the Prob. of tstatistics $(0.024)$ is less than $5 \%$ level of significance, $(0.024<0.05)$ the study reject the null hypothesis $\left(\mathrm{H}_{0}\right)$, as a result, the alternate hypothesis $\left(\mathrm{H}_{\mathrm{a}}\right)$ which says that there is a significant relationship between career counseling and worker efficiency was accepted.

Table 2 shows the result on the coefficient determination $\left(\mathrm{r}^{2}\right)$ on career counseling on worker efficiency as 0.76 . This implies $76 \%$ of the total variation in worker efficiency is accounted for, by the level of career counseling. The $\mathrm{R}$ is 0.876 this means there is a strong relationship between career counseling and worker efficiency in Private Higher Education in Central Java, Indonesia..

Table 3 shows the correlation coefficient between career counseling and worker efficiency. The $\mathrm{R}$ is 0.876 the aforementioned result shows that there is a strong relationship between career counseling and worker efficiency in Private Higher Education in Central Java, Indonesia..

Table 4 shows the result of career mentoring on the quality of employee job performance. The coefficient of the constant term is -325 and its associated tvalue is statistically significant at $5 \%$ level. 
This however, implies that at zero level of performance, in their operations, career mentoring constant, the level of the quality of employee job performance, will decrease by $3 \%$. In other words, the coefficient of the regression result on career mentoring equally has a negative sign. This implies that career mentoring has a significant effect on the quality of employee job performance in Private Higher Education in Central Java, Indonesia.. Therefore, Since the Prob. of tstatistics $(0.000)$ is less than $5 \%$ level of significance, $(0.000<0.05)$ the study reject the null hypothesis $\left(\mathrm{H}_{0}\right)$, as a result, the alternate hypothesis $\left(\mathrm{H}_{\mathrm{a}}\right)$ was accepted, hence, There is a significant relationship between career mentoring and quality of employee job performance in Private Higher Education in Central Java, Indonesia. .

More so, Table 5 shows the regression result on the coefficient of determination $\left(\mathrm{r}^{2}\right)$ on career mentoring on the quality of employee job performance. $\mathrm{r}^{2}=0.582$. This implies that $58 \%$ of the total variation on the quality of employee job performance is accounted for, by career mentoring, in Private Higher Education in Central Java, Indonesia. $\mathrm{R}=0.763$ this suggests a positive relationship between career mentoring and the quality of employee job performance in Private Higher Education in Central Java, Indonesia. .

Table 6 shows the correlation coefficient between career mentoring and the quality of employee job performance in Private Higher Education in Central Java, Indonesia. The $\mathrm{R}$ is 0.763 the aforementioned result shows that there is a positive relationship between career mentoring and the quality of employee job performance in Private Higher Education in Central Java, Indonesia..

Table 7 shows the result of skill assessment on the efforts of employee job performance. The coefficient of the constant term is -312 and its associated tvalue is statistically significant at $5 \%$ level.
This however, implies that at zero level of performance, in their operations, holding skill assessment constant, the level of the efforts of employee job performance will decrease by $3 \%$. In other words, the coefficient of the regression result on skill assessment training equally has a negative sign. This implies that skill assessment training has a significant effect on the efforts of employee job performance in Private Higher Education in Central Java, Indonesia. .

Therefore, Since the Prob. of tstatistics $(0.000)$ is less than $5 \%$ level of significance, $(0.000<0.05)$ the study reject the null hypothesis $\left(\mathrm{H}_{0}\right)$, as a result, the alternate hypothesis $\left(\mathrm{H}_{\mathrm{a}}\right)$ was accepted, hence, There is a significant relationship between skill assessment training and the efforts of employee job performance in Private Higher Education in Central Java, Indonesia. .

Table 8 shows the regression result on the coefficient of determination $\left(\mathrm{r}^{2}\right)$ on skill assessment training on the efforts of employee job performance. The $r^{2}=0.760$ this implies that $76 \%$ of the total variation on the efforts of employee job performance is accounted for, by skill assessment training in Private Higher Education in Central Java, Indonesia. .

The $\mathrm{R}=0.872$ this suggests a strong relationship between skill assessment training and the efforts of employee job performance in Private Higher Education in Central Java, Indonesia. And it is believed to have an opportunity in the acquirement of knowledge, improvement of skills, concepts, rules, changes of attitudes and behaviors in the organizational settings. Huselid (1995) affirm that providing formal and informal training for new employees have an influence on employee's development.

Table 9 shows the correlation coefficient between skill assessment training and the efforts of employee job performance in Private Higher Education in Central Java, Indonesia. . 
The $\mathrm{R}$ is 0.872 the aforementioned result shows that there is a positive relationship between skill assessment training and the efforts of employee job performance in Private Higher Education in Central Java, Indonesia. The finding was in line with the principles of Cole (2002) suggestion on purpose of facilitating training as it was to create a learning media directed towards the acquisition of specific knowledge and skills for the purpose of an occupation or task. The results of this study support A.M.Diriye (2015) research which found hat career development practices (career planning, coaching, counselling and mentoring) greatly affected employee commitment and engagement at Nairobi County Government. Career Development Programs enhance employee performance and have a positive impact on an organization's overall effectiveness. The challenge facing many organizations today is overcoming the traditional view of career development as a means to develop the most promotable employees. The cultural shift toward employee empowerment, technological advancement, a changing workforce (diversity, work-life balance, etc.) and the new role of managers, are very much in line with the career development initiative.

Among the observed variables, employee's skill suggests to be one of the best factors of organizational growth. Essentially, close and positive association exists among the observed independent variables. Individuals have a lot to gain from employee development programs, which is implied in the name itself. Access to training, including self-managed learning and support for gaining qualifications, can be important in opening up career pathways for existing employees to jobs which require particular skills or qualifications. Careers are also influenced by informal processes though which employees receive advice from others, and those with jobs to fill use their internal networks to gain intelligence on possible applicants. These informal processes are very important and should not be seen in a negative way (Hirsh et al., 2007). Employees may need more encouragement to use informal career support effectively. College graduates are often looking to large firms to get some solid training to set themselves up for the future, but this can be a strain to organizations that risk losing freshly trained employees within a couple of years (Feldman, 2000). Young professionals, especially those in fast paced industries like information technology, recognize that knowledge is power and they need to keep their skills current to succeed. Many of these people even recognize the value of training and would prefer that to an increased salary (Dillich, 2000). It is also unrealistic to expect a recent college graduate to be fully prepared for the ever-changing business world (Gerbman, 2000). Young people with entrepreneurial aspirations are also finding that they lack the money and experience for such ventures, so they can use employee development programs to prepare themselves for a future of selfemployment (Feldman, 2000).

\section{CONCLUSION AND RECOMMEN- DATION}

It is important for organization to get skilled and capable employees for better performance, and employees will be than competent when they have the knowledge and skill of doing the task. Career development would provide opportunities to the employees to make a better career life and get better position in organization. In doing so, organizations efficiency would be increased. On the other hand, employees are the resources and assets of an organization if they are skilled and trained would perform better than those who are unskilled and untrained.

Based on the findings, the study concludes that Private Higher Education in Central Java, can increasingly improve employee job performance if considerable attention is given to career development in their organization. 
However, the result shows that worker efficiency has a significant effect on career counseling. Therefore, for improved work efficiency, organizations are encouraged to provide an institutional framework that can allow its employees to acquire practical skill, and learning experience through career counseling. Organizational performance could be attained through career mentoring programs, because the result shows that the quality of employee job performance has a considerable effect on career mentoring. The quality of employee job performance can be sustained through career mentoring especially when the trained person provides guidance and advice used to complement learning on the job. The knowledge acquired through career mentoring has a propulsive effect on the quality of employee job performance. The result also revealed that skill assessment training has a significant effect on the efforts of employee job performance.

The study recommends that Private Higher Education in Central Java should encourage and entrench career counseling activities as a leeway of providing a sustainable framework upon which employees' acquire the needed operational skills that will enhance their job performance in a typical organization. Also, a considerable attention must be directed towards instituting career mentoring programs that have the capacity of educating the employees on the job for improved job performance in the organization. HR professionals can play a vital part in establishing and nurturing the relationship between performance appraisal and career development by keeping the concept of "talent development" clearly in mind and by cultivating systems and individuals that support it. This constitutes a significant shift in perspective. Thus the HR professional must take on the role of change agent by introducing and initiating a stronger relationship between performance appraisal and career development. He or she will need to promote this relationship and lay the groundwork for managers' and employees' new roles and for this new perspective. Essentially the initial intervention for creating an interactive system is training and education.

\section{Limitations}

One major limitation of this study was that it was based only on private higher education in Central Java and other public higher education were not included. Another limitation was that due to the time constraint only 10 private higher education of central Java were studied other of private higher education in the district were not included.

\section{References}

Agba, A. M. O., Nkpoyen, F., \& Ushie, E. M. (2010). Career development and employee commitment in industrial organizations in Calabar, Nigeria. American journal of scientific and industrial research, 1(2), 105-114.

Agulanna, E. C., \& Awujo, A. C. (2005). Human Resource Management-A graphic Approach. Owerri: Career Publishers.

Aldefer \& Aryam, P. (2004), The Need for Career Development in Organization. Journal of Managerial Psychology and Applied Psychology, 15(9), 212234.

Asfaw, A. M., Argaw, M. D., \& Bayissa, L. (2015). The impact of training and development on employee performance and effectiveness: A case study of District Five Administration Office, Bole SubCity, Addis Ababa, Ethiopia. Journal of Human Resource and Sustainability Studies, 3(04), 188-202. 
Coates, T. K. (2017). Hearing the voices of Generation Y employees: a hermeneutic phenomenological study. Human Resource Development International, 20(1), 37-67. (Tabitha)

Cole, G. A. (2002). Personnel and human resource management. Cengage Learning EMEA.

De Pater, I. E., Van Vianen, A. E., Bechtoldt, M. N., \& Klehe, U. C. (2009). Employees'challenging Job Experiences And Supervisors'evaluations Of Promotability. Personnel Psychology, 62(2), 297-325.

Dillich, S. (2000). Corporate Universities. Computing Canada, 26(16), 25-25

Diriye, A. M. (2015). Perceived relationship between career development and employee commitment and engagement at Nairobi city county government. Unpublished Master's thesis, University of Nairobi, Nairobi Kenya). Retrieved from http://erepository. uonbi. ac. ke.

Feldman, M. S. (2000). Organizational routines as a source of continuous change. Organization science, 11(6), 611-629.

Hameed, A. \& Waheed, A. (2011), Employee Development and its effects on Employee Performance. Journal of Vocational Behaviour. 25 (7), 98-105.

Hirsh, W. (2007). Career Development In Employing Organisations: Practices And Challenges From A UK Perspective. Journal Institute for Employment Studies, 2(10), 18.

Hoffman, A. \& Woehr, D. J. (2006). A Quantitative Review of the Relationship between Personsorganization fit and Behavioural outcomes. Boston: George publications.
Huselid, M. A. (1995). The impact of human resource management practices on turnover, productivity, and corporate financial performance. Academy of management journal, 38(3), 635-672.

Ito, J. K., \& Brotheridge, C. M. (2005). Does supporting employees' career adaptability lead to commitment, turnover, or both?. Human Resource Management, 44(1), 5-19.

John, H. L. (2000). Impact of Career Development on Performance. Journal of Organizational Behavior, 4(5), 321-328.

Judy, P., Philip, B, \& Gwolym, P. (2001), Person-Organization Fit: The Potential Stumbling Block of subculture. Journal of Managerial Psychology and Applied Psychology, Glasgow University, 16(10), 34-40.

Judy, P., Philip, B, \& Gwolym, P. (2001). Person-Organization Fit: The Potential Stumbling Block of subculture. Journal of Managerial Psychology and Applied Psychology, 16(10), 34-40.

Klein, K.L., \& Weiner, Y (1977). Interest Congruence as a Moderator of the Relationship between job tenure and job stratification and mental health. Journal of Vocational Behavior, 4(3), 15-20.

Krostol, A. L. (1996). Person-Organization Fit. An Integrative Review of its Conceptualizations, Measurement and Implications. Florida: Park publications.

Martins, N. M. (2000). The Indispensable role of Career Mentoring on Employee Job Performance in Organization. Journal of Business Studies, 2(3) 24-32. 
Merchant, R.C. (2011). The Role of Career Development in Improving Organizational Effectiveness and Employee Development Professional Standard Unit. Boston: Puis Publications.

Murerwa, T. G. (2017). Career Development And Performance Appraisal. International Journal of Academic Research and Reflection, 5(3), 66-73.

Nwachukwu, C. C. (2000), Human Resource Management. PortHarcourt: Kalama Publications.

Osibanjo, A. O., Oyewunmi, A. E., \& Ojo, I. S. (2014). Career Development as a Determinant Of Organizational Growth: Modeling The Relationship Between These Constructs in The Nigerian Banking Industry. American International Journal of Social Sciences, 3(7), 67-76.

Parvin, M. M. \& Kabir, M. N. (2011). Factors Affecting Employee Job Satisfaction Of Pharmaceutical Sector. Australian Journal of Business and Management Research, 1(9), 113-123.

Patrick, H.A. \& Kumar, A .(2011). Career Management, Employee Development and Performance. India IT information Technology Organizations Business Journal, 1(5), 2431 .

Rafferty, A. E., \& Griffin, M. A. (2006). Perceptions of organizational change: A stress and coping perspective. Journal of applied psychology, 91(5), 1154.

Ragins, B. R., \& McFarlin, D. B. (1990). Perceptions of mentor roles in crossgender mentoring relationships. Journal of Vocational Behavior, 37(3), 321-339.

Scandura, T. A., \& Williams, E. A. (2004). Mentoring and transformational leadership: The role of supervisory career mentoring. Journal of vocational behavior, 65(3), 448-468.
Savickas, M. L. \& Savickas, S. (2017) in Reference Module in Neuroscience and Biobehavioral Psychology.

Sosik, J. J., \& Godshalk, V. M. (2000). Leadership styles, mentoring functions received, and job-related stress: a conceptual model and preliminary study. Journal of organizational behavior, 21(4), 365390.

Tadic, I. (2005). Career Development of Graduates in Economic and Busines administration in Croatia. Unpublished Master thesis, University of Port-Harcourt.

Tahir, N., Yousafzai, I. K., Jan, S., \& Hashim, M. (2014). The Impact of Training and Development on Employees Performance and Productivity A case study of United Bank Limited Peshawar City, KPK, Pakistan. International Journal of Academic Research in Business and Social Sciences, 4(4), 86-98.

Van Scotter, J., Motowidlo, S. J., \& Cross, T. C. (2000). Effects of task performance and contextual performance on systemic rewards. Journal of applied psychology, 85(4), 526. 


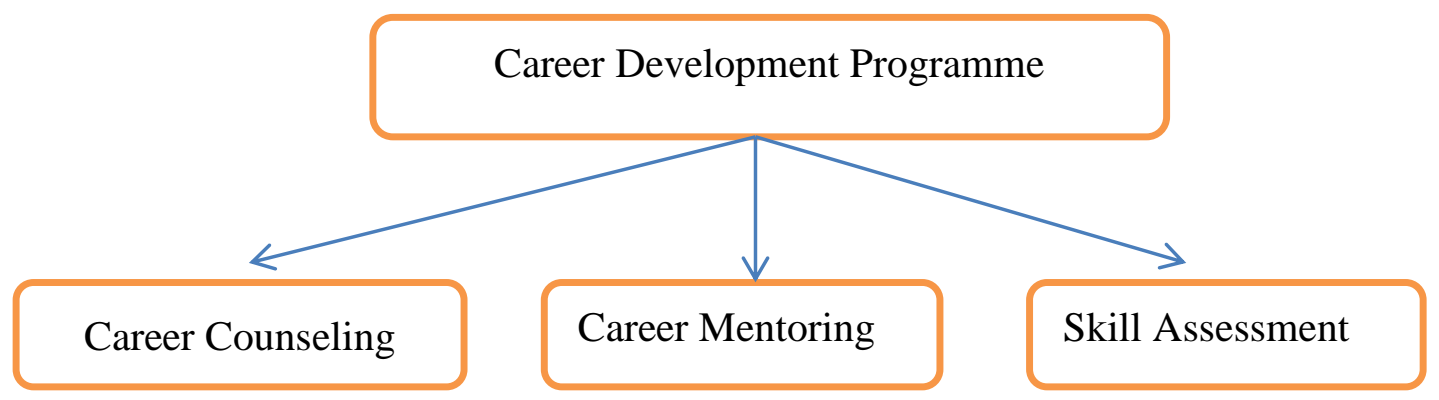

Figure 1. Components of a Career Development Program

\section{Results}

Data for this study were presented and analyzed based on the specific objective. The SPSS 20.0 package was used to regress the variables on the specific objectives of the study.

\section{For hypothesis one:}

Table 1. Coefficients

\begin{tabular}{|c|c|c|c|c|c|}
\hline \multicolumn{3}{|c|}{ Unstandardized Coefficients } & \multicolumn{3}{|c|}{ Standard coefficients } \\
\hline Model & B & STD Error & Beta & $\mathrm{t}$ & Sig. \\
\hline (Constant) & -303 & .056 & & -8.268 & .000 \\
\hline Career & .517 & .016 & .648 & 34.852 & .024 \\
\hline
\end{tabular}

Counseling

Dependent Variable: Worker Efficiency

Source: Analysis of Statistical data (SPSS 20.0)

Table 2. Model Summary

\begin{tabular}{llllll}
\hline Model & $\mathrm{R}$ & R Square & $\begin{array}{l}\text { Adjusted } \\
\text { Square }\end{array}$ & $\mathrm{R}$ & Std. Error of Estimates \\
\hline & 0.876 & 0.76 & 0.717 & 0.17173 \\
\hline
\end{tabular}

Source: Analysis of Statistical data (SPSS 20.0)

Table 3. Correlations

\begin{tabular}{cccc}
\hline & & $\mathrm{Cc}$ & Worker Efficiency \\
\hline Career & Pearson Correlation & 1 & 0.876 \\
Counseling & Sig. (2-tailed) & & .000 \\
& $\mathrm{~N}$ & 250 & 250 \\
\hline Worker & Pearson Correlation & 0.876 & 1 \\
Efficiency & Sig. (2-tailed) & .000 & 250 \\
& $\mathrm{~N}$ & 250 &
\end{tabular}

Source: Analysis of Statistical data (SPSS 20.0)

\section{For Hypothesis Two}

Table 4. Coefficients

\begin{tabular}{|c|c|c|c|c|c|}
\hline \multicolumn{3}{|c|}{ Unstandardized Coefficients } & \multicolumn{3}{|c|}{ Standard coefficients } \\
\hline Model & $\mathrm{B}$ & STD Error & Beta & $\mathrm{t}$ & Sig. \\
\hline (Constant) & $-\quad 325$ & .044 & & 7.268 & .000 \\
\hline Career mentoring & .317 & .023 & .128 & 24.852 & .000 \\
\hline
\end{tabular}

Dependent Variable: Quality of Employee job performance 
Source: Analysis of Statistical data (SPSS 20.0)

Table 5. Model Summary

\begin{tabular}{ccccc}
\hline Model & $\mathrm{R}$ & R Square & $\begin{array}{c}\text { Adjusted R } \\
\text { Square }\end{array}$ & $\begin{array}{c}\text { Std. Error of } \\
\text { Estimates }\end{array}$ \\
\hline & 0.763 & 0.582 & 0.563 & 0.23654 \\
\hline
\end{tabular}

Source: Analysis of Statistical data (SPSS 20.0)

Table 6. Correlations

\begin{tabular}{lccc}
\hline & & $\begin{array}{c}\text { Career } \\
\text { Mentoring }\end{array}$ & $\begin{array}{c}\text { Quality of } \\
\text { Employee Job Performance }\end{array}$ \\
\hline Career & Pearson Correlation & 1 & 0.763 \\
Mentoring & Sig. (2-tailed) & & .000 \\
& $\mathrm{~N}$ & 250 & 250 \\
\hline Quality of & Pearson Correlation & 0.763 & 1 \\
Employee Job & Sig. (2-tailed) & .000 & 250 \\
Performance & $\mathrm{N}$ & 250 & \\
& & &
\end{tabular}

Source: Analysis of Statistical data (SPSS 20.0)

\section{For Hypothesis Three}

Table 7. Coefficients

\begin{tabular}{|c|c|c|c|c|c|}
\hline \multicolumn{3}{|c|}{ Unstandardized Coefficients } & \multicolumn{3}{|c|}{ Standard coefficients } \\
\hline Model & $\mathrm{B}$ & STD Error & Beta & $\mathrm{t}$ & Sig. \\
\hline (Constant) & 312 & .022 & & -3.216 & .000 \\
\hline Skill Assessment & .217 & .014 & .125 & 13.324 & .000 \\
\hline
\end{tabular}

Dependent Variable: Efforts of Employee job performance

Source: Analysis of Statistical data (SPSS 20.0)

Table 8. Model Summary

\begin{tabular}{ccccc}
\hline Model & $\mathrm{R}$ & R Square & $\begin{array}{c}\text { Adjusted R } \\
\text { Square }\end{array}$ & $\begin{array}{c}\text { Std. Error of } \\
\text { Estimates }\end{array}$ \\
\hline & 0.872 & 0.760 & 0.624 & 0.2563 \\
\hline
\end{tabular}

Source: Analysis of Statistical data (SPSS 20.0)

Table 9. Correlations

\begin{tabular}{clcc}
\hline & & $\begin{array}{c}\text { Skill } \\
\text { Assessment }\end{array}$ & $\begin{array}{c}\text { Efforts of } \\
\text { Employee job Performance }\end{array}$ \\
\hline Skill & Pearson Correlation & 1 & 0.872 \\
Assessment & Sig. (2-tailed) & 250 & .000 \\
& $\mathrm{~N}$ & 0.872 & 250 \\
\hline Efforts of & Pearson Correlation & .000 & 1 \\
Employee job & Sig. (2-tailed) & 250 & 250 \\
Performance & $\mathrm{N}$ & \\
\hline
\end{tabular}

Source: Analysis of Statistical data (SPSS 20.0) 